実験・技術・調查報告・Report

\title{
軽石およびシラスから重金属吸着剤の合成について
}

\author{
泊 正 雄 - 坂 本 栄 治*

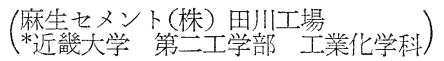

\section{Synthesis of the Adsorbent for Heavy Metal Ions from Pumice and Shirasu}

\author{
By \\ Masao TOMARI and Eiji SAKAMOTO* \\ (Aso Cement Co. Ltd., Tagawa Factory, *Kinki University)
}

\begin{abstract}
The adsorbent for heavy metal ions was synthesized by the hydrothermal treatment of pumice or shirasu and sodium hydroxide-sodium chloride solution.

The synthesized adsorbent was identified by the X-ray diffraction method, and it's cation exchange capacities were measured. The adsorption capacities of the synthesized adsorbent were $0.4 \sim 1.9 \mathrm{meq} / \mathrm{g}$ for $\mathrm{Cu}, \mathrm{Cr}, \mathrm{Cd}$ etc.
\end{abstract}

[Received July 15, 1972]

\section{1. え がき}

昭和 46 年 5 月公害防止法が施行され, 工場廃水およ

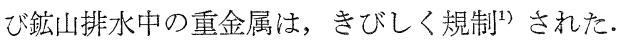

これらの除去には一般にイオン交換樹脂が用いられて いるが，価格は高いようである。このため，鹿児島県古 江産の軽石およびシラスを水酸化ナトリウム溶液などで 処理して重金属吸着剂の合成を行なったので，その結果 につき報告する。

\section{2. 試 験 方 法}

\section{1 原料および処理}

使用原料としては鹿児島県古江産軽石およびシラス で, その化学分析值およびアルカリ可溶成分の分析值を 表-1 に示す.

この軽石およびシラスを乾燥後, クラッシャーで $5 \mathrm{~mm}$ 以下に粗研後, さらに0.6 mm 以下に粉砕した試 料 $50 \mathrm{~g}$ を, 濃度の異なる水酸化ナトリウム溶液および 水酸化ナトリウムと塩化ナトリウムの混合溶液 $200 \mathrm{cc}$

表-1 軽石, シラスおよびこれらの可溶成分の分析值. (\%)

\begin{tabular}{|c|c|c|c|c|c|c|c|c|}
\hline 試 料 & Ig. loss & $\mathrm{SiO}_{2}$ & $\mathrm{Al}_{2} \mathrm{O}$ & $\mathrm{O}_{3} \mathrm{Fe}_{2} \mathrm{O}_{3}$ & ${ }_{3} \mathrm{CaO}$ & $\mathrm{MgO}$ & $\mathrm{Na}_{2} \mathrm{O} \mathrm{K} \mathrm{K}_{2} \mathrm{O}$ & Total \\
\hline 軽 石 & 4.6 & 70.1 & 15.1 & 2.2 & 2.1 & 0.5 & $3.1 \quad 2.9$ & 9100.6 \\
\hline シラス & 0.3 & 76.1 & 13.1 & 1.7 & 1.0 & 0.3 & $3.4 \quad 3.3$ & $\begin{array}{l}3 \quad 99.2 \\
\end{array}$ \\
\hline \multirow{2}{*}{ 試 料 } & \multirow{2}{*}{ In. sol } & & \multicolumn{6}{|c|}{ 可溶 成 分 } \\
\hline & & $\mathrm{Si}$ & $\overparen{\mathrm{O}_{2}}$ & $\mathrm{Al}_{2} \mathrm{O}_{3}$ & $\mathrm{Fe}_{2} \mathrm{O}_{3}$ & $\mathrm{CaO}$ & $\mathrm{MgO}$ & Total \\
\hline 整 石 & 46.6 & 42 & 0 & 7.8 & 1.1 & 0.7 & 0.3 & 51.9 \\
\hline シラス & 43.9 & 44 & .1 & 8.7 & 1.3 & 0.7 & 0.3 & 55.1 \\
\hline
\end{tabular}

で時間, 温度を変えて処理した. 処理生成物は洗浄後, $105^{\circ} \sim 110^{\circ} \mathrm{C}$ で乾燥した。処理生成物の同定は粉末 X線 回折法 (東芝 (株) 製 AOG-102 型)によって調べた.

測定条件は次のようである。

radiation/filter $\mathrm{Cu} / \mathrm{Ni}$, voltage $30 \mathrm{kV}$, current $16 \mathrm{~mA}$, scale factor 4, multiplier 1, time constant 2 , slits $1-1-0.3 \mathrm{~mm}$, scanning speed $1 \% \mathrm{~min}$, chart speed $10 \mathrm{~mm} / \mathrm{min}$.

\section{2 塩基置換容量の測定 ${ }^{2)}$}

塩基置換容量は約 100 メッシュの試料 $1 \mathrm{~g}$ を石英粉 末 $8 \mathrm{~g}$ とよく混合し, 浸出管に入れ, $1 \mathrm{~N}$ 酢酸アンモニウ ム溶液 $(\mathrm{pH}$ 7) $100 \mathrm{ml}, 80 \%$ エ夕ノール $(\mathrm{pH} 7) 50 \mathrm{ml}, 10$ \%塩化カリウム溶液 $100 \mathrm{ml}$ の順に浸出させ, 最終浸出溶 液中の $\mathrm{NH}_{4}+$ をセミミクロキエルダール法で定量した.

\section{3 重金属の吸着}

蒸留水にそれぞれ硫酸銅, 塩化力ドミウムおよびクロ

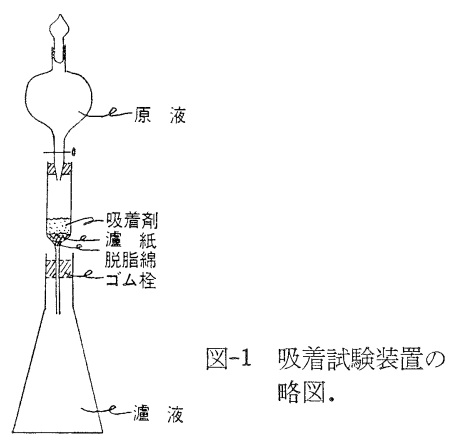


ム酸カリ（亜硝酸ソーダ, 硫酸で 6 価のクロムを 3 価に して）を溶解し，10 ppmの 銅，クロムおよびカドミウ 厶溶液を作り，図-1 に示す装置で， $50 \mathrm{cc}$ ゔつ濾過し， 各濾液につき濃度を測定した。なお銅，カドミウムは原 子吸光分析器 (日立 (株) 製 202 型) で, ク口ムは吸 光光度分析器 (島津 (株) 製 20 型) で測定した.

\section{3. 結果と考察}

\section{1 アルカリ処理による生成物}

軽石打よびシラスの水酸化ナトリウム溶液, 水酸化ナ トリウムと塩化ナトリウム混合溶液による処理により， ゼオライト類似物質が生成するが，その生成量は処理時 間，アルカリ濃度，温度によって異なる。

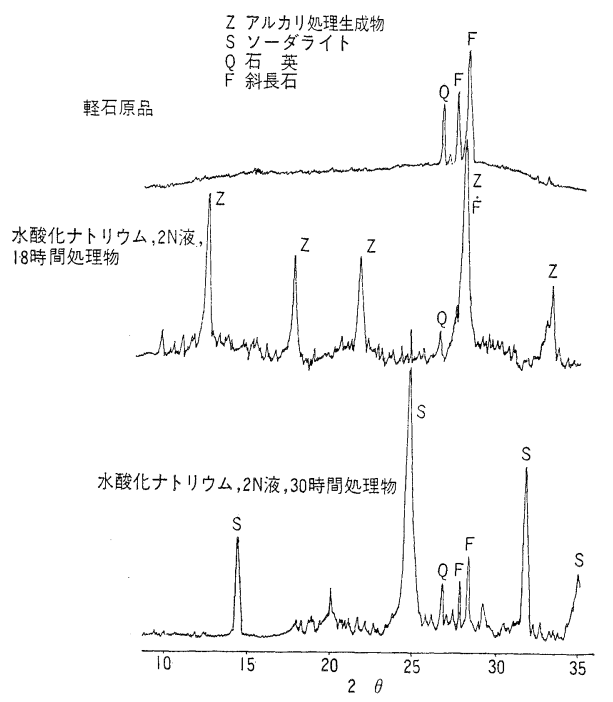

図-2 水酸化ナトリウムの濃度と合成時間の変化による 軽石からのアルカリ処理生成物拉よびソーダライ トのX線回折図。

アルカリ処理生成物の $\mathrm{X}$ 線回折図の一部を図-2 に示 す.アルカリ濃度の低い場合には7.19, 5.05, 3.20 ̊ な どの新らしい回折線が認められるが，これらの回折線は ゼオライトの一種である Sodium Aluminum Silicate Hydrate $^{3)}$ の回折線とほとんど一致することから，軽石 およびシラスは，アルカリ処理によって， Sodium Aluminum Silicate Hydrate に変化することが認めら れた.アルカリ処理生成物およびソーダライトのX線回 折結果を表-2 に示す.

アルカリ濃度が高くなるにつれて，ソーダライトの回 折線が認められ，4 $\mathrm{N}$ 以上ではゼオライト類似のアルカ リ処理生成物の回折線はほとんど認められず，ソーダラ イトと原料に含まれていた石英, 斜長石の回折線のみが 認められる。

アルカリ濃度とアルカリ処理生成物およびソーダライ トの生成量の関係を図-3 に示す。
表-2 軽石のアルカリ処理生成物およびソーダライトの $\mathrm{X}$ 線回折結果.

\begin{tabular}{|c|c|c|c|c|c|}
\hline \multicolumn{3}{|c|}{$\begin{array}{l}\text { 俥圣石の } \mathrm{NaOH}(2 \mathrm{~N} \text { 液 }) 18 \text { 時間 } \\
\text { アルカ処理生成物 }\end{array}$} & \multicolumn{3}{|c|}{$\begin{array}{l}\text { Sodium aluminum silicate } \\
\text { hydrate (Zeolite) } \\
\text { ASTM card No. } 12-0195^{3)}\end{array}$} \\
\hline$d(\AA)$ & $I / I_{0}$ & $\operatorname{Min}^{* 1)}$ & $d(\AA)$ & $I / I_{0}$ & $(h k l)$ \\
\hline 9.56 & 27 & Z & 9.5 & 60 & 001 \\
\hline 8.27 & 13 & Z & 8.2 & 40 & 101 \\
\hline 7.19 & 66 & $Z$ & 7.2 & 80 & 200 \\
\hline 6.96 & 11 & $Z$ & 7.0 & 40 & 020 \\
\hline 5.60 & 9 & $Z$ & 5.6 & 40 & 201 \\
\hline 5.42 & 8 & $Z$ & 5.4 & 20 & 211 \\
\hline 5.05 & 43 & Z & 5.0 & 80 & 220 \\
\hline 4.71 & 8 & $Z$ & 4.68 & 20 & 102 \\
\hline 4.51 & 7 & $Z$ & 4.50 & 20 & 310 \\
\hline 4.33 & 14 & $Z$ & 4.34 & 80 & 112 \\
\hline 4.09 & 42 & Z & 4.08 & 80 & $31 \mathfrak{i}$ \\
\hline 3.88 & 9 & Z & 3.88 & 40 & 212 \\
\hline 3.57 & 15 & $Z$ & 3.58 & 60 & 400 \\
\hline 3.44 & 8 & $Z$ & 3.45 & 60 & 222 \\
\hline 3.35 & 16 & $Z, Q$ & 3.35 & 60 & 312 \\
\hline 3.23 & 27 & $F, Z$ & 3.24 & 60 & 013 \\
\hline 3.20 & 100 & $F, Z$ & 3.19 & 100 & 420 \\
\hline 2.93 & 12 & $Z$ & 2.93 & 80 & 203 \\
\hline 2.70 & 33 & $Z$ & 2.73 & 60 & 223 \\
\hline \multicolumn{6}{|c|}{ 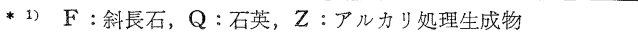 } \\
\hline \multicolumn{3}{|c|}{$\begin{array}{c}\text { 軽石の } \mathrm{NaOH} \text { (2N 液) } \\
\text { 水熱処理物 } \\
\text { ソーダライト }\end{array}$} & \multicolumn{3}{|c|}{$\begin{array}{c}\text { Sodalite } \\
\text { ASTM card No. 3-0338 }\end{array}$} \\
\hline$d(\AA)$ & $I / I_{0}$ & $\operatorname{Min}^{* 2)}$ & $d(\mathrm{~A})$ & $I / I_{0}$ & $(h k l)$ \\
\hline 6.34 & 48 & $\mathrm{~S}$ & 6.3 & 17 & 110 \\
\hline 4.42 & 23 & $\mathrm{~S}$ & 4.42 & 3 & 200 \\
\hline 3.64 & 100 & $\mathrm{~S}$ & 3.63 & 100 & 211 \\
\hline 3.35 & 23 & $\mathrm{Q}$ & & & \\
\hline 3.23 & 24 & $F$ & & & \\
\hline 3.20 & 37 & $\mathrm{~F}$ & & & \\
\hline 2.81 & 81 & $\mathrm{~S}$ & 2.81 & 5 & 310 \\
\hline 2.56 & 30 & $\mathrm{~S}$ & 2.56 & 13 & 222 \\
\hline
\end{tabular}

水酸化ナトリウム濃度が $2 \mathrm{~N}$ で $105^{\circ} \sim 110^{\circ} \mathrm{C}, 18$ 時 間処理の場合，アルカリ処理生成物の生成量は最大とな り，4N 以上ではソーダライトが非常に早く生成する. また，塩化ナトリウムの影響は図-4に示すように，水 酸化ナトリウム $2 \mathrm{~N}$ 液 $100 \mathrm{ml}$ に塩化ナトリウムを $5 \mathrm{~g}$ 添加した混合液で $105^{\circ} \sim 110^{\circ} \mathrm{C}, 18$ 時間処理でアルカリ 処理生成物の生成量が大きくなる。

また，軽石のアルカリ処理生成物の化学分析值を表-3 に示す．原品軽石にくらべて，アルカリ処理生成物はす べて $\mathrm{SiO}_{2}$ が減少し， $\mathrm{Na}_{2} \mathrm{O}, \mathrm{Al}_{2} \mathrm{O}_{3}$ が増加している.す なおち，表-1 に示したように，軽石およびシラスは可 溶成分として $\mathrm{SiO}_{2}$ が多く，アルカリ処理で $\mathrm{Si}$ 成分が 溶出し，アルカリ処理生成物の生成に伴って, $\mathrm{Na}$ 成分 が多くなるものと考えられる。

\section{2 塩基置換容量}

軽石, 天然ゼオライトおよび軽石のアルカリ処理生成 物の塩基置換容量を 表 -4 に示す.

軽石はほとんど塩基置換能がなく，軽石のアルカリ処 理生成物および天然ゼオライトはかなり塩基置換能があ 


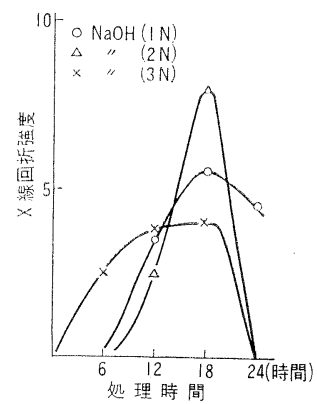

処理時間に上当軽石からのアルカリ処理生成 物の生成量々水酸化ナトリウム温度の関係 (温度 $105^{\circ} \sim 110^{\circ} \mathrm{C}$ )

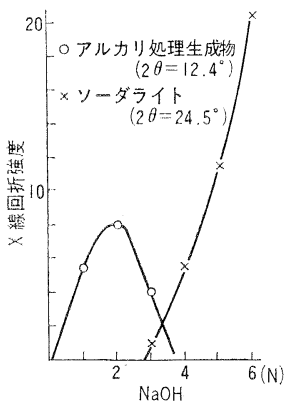

温度 $105^{\circ} \sim 110^{\circ} \mathrm{C}$

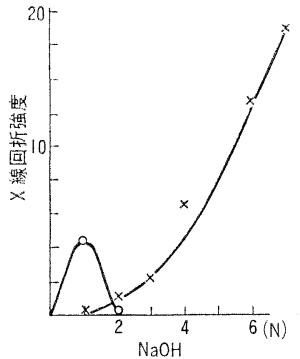

温度 $105^{\circ} \sim 110^{\circ} \mathrm{C}$ \{処理時間 24 特間

圆-3 水酸化ナトリウムの濃度変化による軽石からのアルカリ処理生成物とソーダライトの生成状況.

表-3 軽不からのアルカリ処理生成物の分析値. $\%$

\begin{tabular}{lccccccccccc}
\hline 烒 & Ig. loss & $\mathrm{SiO}_{2}$ & $\mathrm{Al}_{2} \mathrm{O}_{3}$ & $\mathrm{Fe}_{2} \mathrm{O}_{3}$ & $\mathrm{CaO}$ & $\mathrm{MgO}$ & $\mathrm{Na}_{2} \mathrm{O}$ & $\mathrm{K}_{2} \mathrm{O}$ & \multicolumn{2}{c}{ Total } \\
No. 1 & 12.3 & 52.2 & 22.7 & 3.8 & 2.2 & 1.5 & 4.2 & 1.2 & 100.1 & $\mathrm{NaOH}, 2 \mathrm{~N}$ 液, 18 時間処理 \\
No. 2 & 13.9 & 38.8 & 22.8 & 3.6 & 2.3 & 1.5 & 17.2 & 0.3 & 100.4 & $\mathrm{NaOH}, 2 \mathrm{~N}$ 液, 24 特間処理 \\
No. 3 & 12.2 & 49.6 & 22.4 & 3.6 & 2.8 & 1.6 & 7.2 & 1.2 & 100.6 & $\mathrm{NaOH}, 1 \mathrm{~N}$ 液, 18 時間処理 \\
No. 4 & 13.4 & 46.4 & 22.7 & 3.7 & 2.6 & 1.5 & 8.7 & 1.2 & 100.2 & $\mathrm{NaOH}, 1 \mathrm{~N}$ 液, 24 時間处理 \\
\hline
\end{tabular}

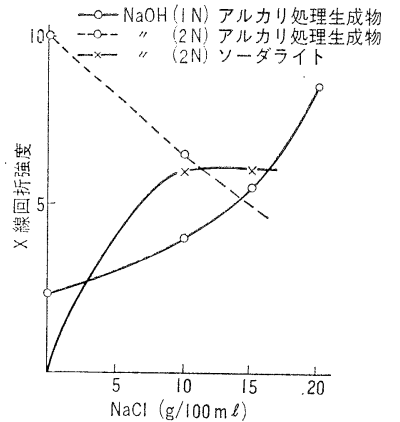

温度 $105^{\circ} \sim 110^{\circ} \mathrm{C}$ 処理時間 18 時間

四-4＼cjkstart塩化ナトリウムと水酸化ナトリウムの濃度変化に よる軽石からのアルカリ処理生成物とソーダライ 卜の生成状況。

表-4 軽石，天然ゼオライトおよび軽石の アルカリ処理生成物の塩基置換容量 (meq/100 g)

\begin{tabular}{|c|c|c|c|}
\hline 誡 & 料 & $\begin{array}{l}\text { 程基置 } \\
\text { 換量 }\end{array}$ & 備 \\
\hline 怪 & 石 & 2.5 & \\
\hline \multirow{3}{*}{\multicolumn{2}{|c|}{ 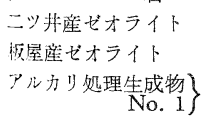 }} & 144 & \\
\hline & & 143 & \\
\hline & & 450 & 水酸化ナトリウム, $2 \mathrm{~N}$ 液, 18 時間处理 \\
\hline$"$ & No. 2$\}$ & 185 & 水酸化ナトリウム, $2 \mathrm{~N}$ 液, 24 時間处理 \\
\hline & No. 3$\}$ & 95 & 水酸化ナトリウム, $1 \mathrm{~N}$ 缏, 18 時間处理 \\
\hline & No. 4$\}$ & 150 & 水酸化ナトリウム, $1 \mathrm{~N}$ 液, 24 時間处理 \\
\hline & No. 5$\}$ & 200 & 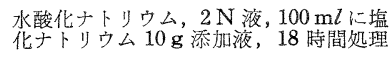 \\
\hline$"$ & No. 6$\}$ & 220 & 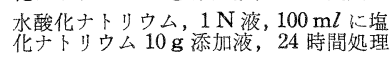 \\
\hline
\end{tabular}

る.特に軽石のアルカリ処理生成物は非常に高くなる.

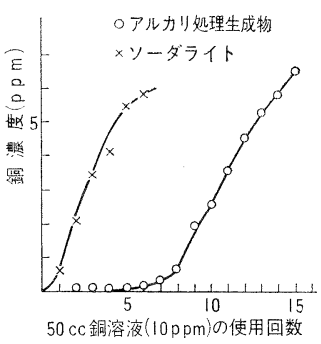

図-5 銅 $10 \mathrm{ppm}$ 液でのアルカリ処理生成物と ソーダライトの吸着試験。(試料 $0.2 \mathrm{~g}$ 当 りの吸着量)

重金属のらち銅，クロムおよびカドミウムにつき 10 $\mathrm{ppm}$ 溶液で吸着試験を行なった。

なお排水基準值以下での吸着量を 表 -5 に示す。表 -5 には比較のために陽イオン交換樹脂の吸着量を示した。 さらに銅の $10 \mathrm{ppm}$ 溶液でのアルカリ処理生成物とソ ーダライトの吸着試験結果の一例を図-5 に示す. すな わち, アルカリ処理生成物は良く吸着するが，ソ一ダラ イトはほとんど吸着しないことがわかる。

\section{4.ま亡 め}

軽石およびシラスは全国的に賦存し，水酸化ナトリウ ム溶液, 水酸化ナトリウムと塩化ナトリウムの混合溶液 などで, $105^{\circ} \sim 110^{\circ} \mathrm{C}$ で，12〜24 時間処理して得られる アルカリ処理生成物は重金属（陽イオン）の吸着性に富 んでいるので，工場廃水や鉱山排水の水処理剤として安 価に製造でき，利用できると考えられる。

試験結果を要約すると次のようである。

1）軽石およびシラスのアルカリ処理生成物はゼオラ 
表-5 軽石, 天然ゼオライトおよび軽石のアルカリ処理生成物の銅, クロム, カドミウムの吸着量. (meq/g)

\begin{tabular}{|c|c|c|c|c|c|}
\hline \multirow{2}{*}{ 試 } & \multirow{2}{*}{ 料 } & \multicolumn{3}{|c|}{ 重金属吸着量 } & \multirow{2}{*}{ 備 } \\
\hline & & 銅 & クロム & カドミウム & \\
\hline 軽 & 石 & $\operatorname{tr}$ & $\operatorname{tr}$ & $\operatorname{tr}$ & \\
\hline 二ッ井産ゼオラ & $\because 11$ & $\operatorname{tr}$ & $\operatorname{tr}$ & $\operatorname{tr}$ & \\
\hline 板屋産ゼオラ & $71 \%$ & $\operatorname{tr}$ & $\operatorname{tr}$ & $\operatorname{tr}$ & \\
\hline \multicolumn{2}{|c|}{ アルカリ処理生成物 No. 1} & 1.5 & 2.8 & 0.7 & 水酸化ナトリウム, $2 \mathrm{~N}$ 液, 18 時間処理 \\
\hline " & No. 2 & 0.7 & 1.6 & 0.4 & 水酸化ナトリウム, $2 \mathrm{~N}$ 液, 24 時間処理 \\
\hline$"$ & No. 3 & 1.0 & 1.6 & 0.6 & 水酸化ナトリウム, $1 \mathrm{~N}$ 液, 18 時間処理 \\
\hline$"$ & No. 4 & 0.9 & 1.8 & 0.4 & 水酸化ナトリウム, $1 \mathrm{~N}$ 液, 24 時間処理 \\
\hline$"$ & No. 5 & 1.4 & 2.4 & 0.7 & $\left\{\begin{array}{l}\text { 水酸化ナトリ只ム, } 2 \mathrm{~N} \text { 液 } 100 \mathrm{ml} \text { に塩化ナトリウム } 10 \mathrm{~g} \text { 添 } \\
\text { 液, } 18 \text { 時間処理 }\end{array}\right.$ \\
\hline " & No. 6 & 0.8 & 1.6 & 0.5 & $\left\{\begin{array}{l}\text { 水酸化ナトリウム, } 1 \mathrm{~N} \text { 液 } 100 \mathrm{ml} \text { に塩化ナトリウム } 10 \mathrm{~g} \text { 添 } \\
\text { 吅液, } 24 \text { 時間処理 }\end{array}\right.$ \\
\hline \multicolumn{2}{|c|}{ Amberlite, $1 \mathrm{R}-120^{4)}$} & $(4.2)$ & & & 陽イオン吸着量 (文献値) \\
\hline \multicolumn{2}{|l|}{ Dowex, $50^{4)}$} & $(4.5)$ & & & 陽イオン吸着量（文献値） \\
\hline
\end{tabular}

イト類似物質の Sodium Aluminum Silicate Hydrate であり,水熱合成温度,アルカリ濃度および処理時間に影 響され, 温度と濃度が高いと早く生成し, 逆に温度と濃 度が低いと長時間かかる。すなわち，水酸化ナトリウム $2 \mathrm{~N}$ 液， $105^{\circ} \sim 110^{\circ} \mathrm{C} ， 18$ 時間㧍よび水酸化ナトリウム $2 \mathrm{~N}$ 液 $100 \mathrm{~m} l$ に塩化ナトリウム $5 \mathrm{~g}, 105^{\circ} \sim 110^{\circ} \mathrm{C}, 18$ 時間処理で最高にアルカリ処理生成物を生成する.

2）ゼオライト類似物質（アルカリ处理生成物）は 銅，クロム，カドミウムなどの重金属イオンを吸着す る.そして，これらの重金属イオンは良く似た吸着特性 を示す.

以上の結果, 軽石およびシラスのアルカリ処理生成物 は重金属イオンの吸着性に富んでいるが, 今後, 重金属 の吸着に何が寄与するか，ガス吸着能力があるかどうか
検討する予定である。

最後にこの試験を行なうにあたり，で援助いただいた田川工 場研究課の方々, X線回折でご指導いただいた山口大学 加藤 敏郎博士および発表を許された麻生セメント(株)の上司に深く 感謝致します。

\section{文献}

1）経済企画庁国民生活局，水質污濁防止法 第 3 条第 1 頂 の総理府令で定める排水基準 (昭和 46 年 5 月 22 日).

2) 分析化学講座 (応用編), “土壌および肥料分析”共立出 版 (1956) p. 35.

3) American Society for Testing and Materials, X-Ray Powder Diffraction Data File.

4) 清水 博, “イオン交換樹脂” 共立出版 (1962) p. 159. $(7 / 15 / 1972$ 受付) 